\title{
Acute promyelocytic leukemia evolving from paroxysmal nocturnal hemoglobinuria: A rare occurrence
}

\author{
Paroksismal noktürnal hemoglobinüriden evrilen akut promyelositik lösemi olgusu: Nadir bir \\ birliktelik
}

Rafet EREN, Tayfur TOPTAŞ, Işık ATAGÜNDÜZ, Tülin FIRATLI TUĞLULAR

\begin{abstract}
A previously healthy 31-year-old female presenting with dyspnea, iron deficiency anemia, pancytopenia, splenomegaly, and abnormal coagulation tests was admitted to the hospital. Hematology consultation additionally revealed that $71 \%$ of cells were indicative of acute promyelocytic leukemia (APL) and the patient tested positive for a $\mathrm{t}(15 ; 17)$ translocation, confirming APL. All-trans retinoic acid (ATRA) therapy was initiated immediately, but the patient exhibited severe dyspnea. This subsequently resulted in circulatory and respiratory arrest, followed by death. Just after death, fluorescein-labelled proaerolysin (FLAER) revealed a paroxysmal nocturnal hemoglobinuria (PNH) monocyte clone of $82 \%$, confirming the diagnosis of PNH. Leukemia can be derived from non-PNH clones in PNH patients. Catastrophic thromboembolic events that could not be controlled with aggressive anticoagulation in a profoundly thrombocytopenic patient without overt disseminated intravascular coagulation (DIC) may suggest co-existent PNH.
\end{abstract}

Keywords: Leukemia, Promyelocytic, Acute, Hemoglobinuria, Paroxysmal

\section{ÖZ}

Bilinen bir hastalığı olmayan ve dispne, demir eksikliği anemisi, pansitopeni, splenomegali ve anormal koagülasyon testleri ile başvuran 31 yaşında kadın hasta hastaneye yatırıldı. Hematoloji değerlendirmede hücrelerin \%71'inin akut promyelositik lösemi (APL) ile uymlu olduğu saptandı ve hastanın $t(15 ; 17)$ translokasyonu pozitif gelerek APL doğruland. All-trans retinoik asit (ATRA) tedavisi hemen başlandı ancak hastada ağır dispne bulguları gelişti. $\mathrm{Bu}$ durum dolaşımsal ve kardiyak arreste yol

Rafet Eren

Department of Hematology, İstanbul Training and Research Hospital, Istanbul, Turkey

e-mail:drrafeteren@gmail.com

Tayfur Toptaş, Işı1k Kaygusuz Atagündüz, Tülin Fıratlı Tuğlular Sub-department of Hematology, Department of Internal Medicine, School of Medicine, Marmara University Hospital, Pendik, İstanbul, Turkey

Submitted/Gönderme: 10.02 .2016

Accepted/Kabul: 12.03.2016 açtı ve ölümle sonuçlandı. Hastanın ölümünden sonra sonuçlanan FLAER tetkikinde paroksismal nokturnal hemoglobinüri tanısını doğrulayan $82 \%$ monosit klonu saptandi. Nokturnal hemoglobinüri hastalarında nokturnal hemoglobinüri dışı klonlardan lösemi gelişebilmektedir. Aşikar yaygın damar içi pıhtılaşması bulguları olmayan ağır trombositopenik bir hastada agresif antikoagülasyonla kontrol edilemeyen katastrofik tromboembolik olaylar eşlik eden nokturnal hemoglobinüriye işaret edebilir.

Anahtar kelimeler: Lösemi, Promyelositik, Akut, Hemoglobinuri, Proksismal

\section{Introduction}

Paroxysmal nocturnal hemoglobinuria $(\mathrm{PNH})$ arises as a result of nonmalignant clonal expansion of one or more hematopoietic stem cells that have acquired a somatic mutation of the $\mathrm{X}$ chromosome gene PIGA [1]. Almost $5-15 \%$ of patients with $\mathrm{PNH}$ experience malignant transformation. Transformation results with acute myeloid leukemia in most cases and acute lymphoblastic leukemia being lesser [2].

Here, we report a case of acute promyelocytic leukemia (APL) evolving from paroxysmal nocturnal hemoglobinuria (PNH). This is the second report of such co-incidence. Immunophenotyping by flow cytometry was used to diagnose APL. Fluorochrome-conjugated (Alexa 488) fluorescein-labelled proaerolysin (FLAER) based flow cytometry was used to identify PNH clones.

\section{Case Report}

A previously healthy 31-year-old female presenting with dyspnea, pancytopenia, splenomegaly, and abnormal coagulation tests was admitted to the hospital for further testing. Her pro-brain natriuretic peptide (proBNP) levels 
were high $(1513 \mathrm{pg} / \mathrm{mL})$, her heart exhibited large right chambers, suggesting pulmonary hypertension, and occlusion of the lobar branches of the bilateral pulmonary arteries was observed, indicating pulmonary embolisms. Cardiological examination revealed orthopnea, bilateral $3+$ pretibial edema, and raised jugular pressure. Hematology consultation detected no overt disseminated intravascular coagulation (DIC) (DIC score of $4[<5]$ ) [3], $5.8 \%$ reticulocytes, and elevated lactate dehydrogenase of 888 $\mathrm{U} / \mathrm{L}(122-240 \mathrm{U} / \mathrm{L})$. However, it was revealed that $71 \%$ of cells were indicative of APL (CD13+, CD33+, CD117+, MPO+, HLADR-) and the patient tested positive for a $\mathrm{t}(15 ; 17)$ translocation, confirming APL (Fig. 1). All-trans retinoic acid (ATRA) therapy was initiated immediately, but the next morning, the patient exhibited severe dyspnea. Her electrocardiogram (ECG) showed a large $\mathrm{S}$ wave in lead I, a Q wave in lead III, and an inverted T wave in lead III indicating acute right heart strain (S1Q3T3 pattern) and arterial blood gas analysis revealed hypoxia and hypocapnia. This subsequently resulted in circulatory and respiratory arrest followed by death, despite $45 \mathrm{~min}$ of cardiopulmonary resuscitation. Cause of death was recorded as probable thrombotic DIC secondary to APL, based on the specific ECG pattern consistent with massive pulmonary embolism and the arterial blood gas analysis. Just after death, FLAER revealed a PNH monocyte clone of $82 \%$, confirming the diagnosis of PNH (Fig. 2)

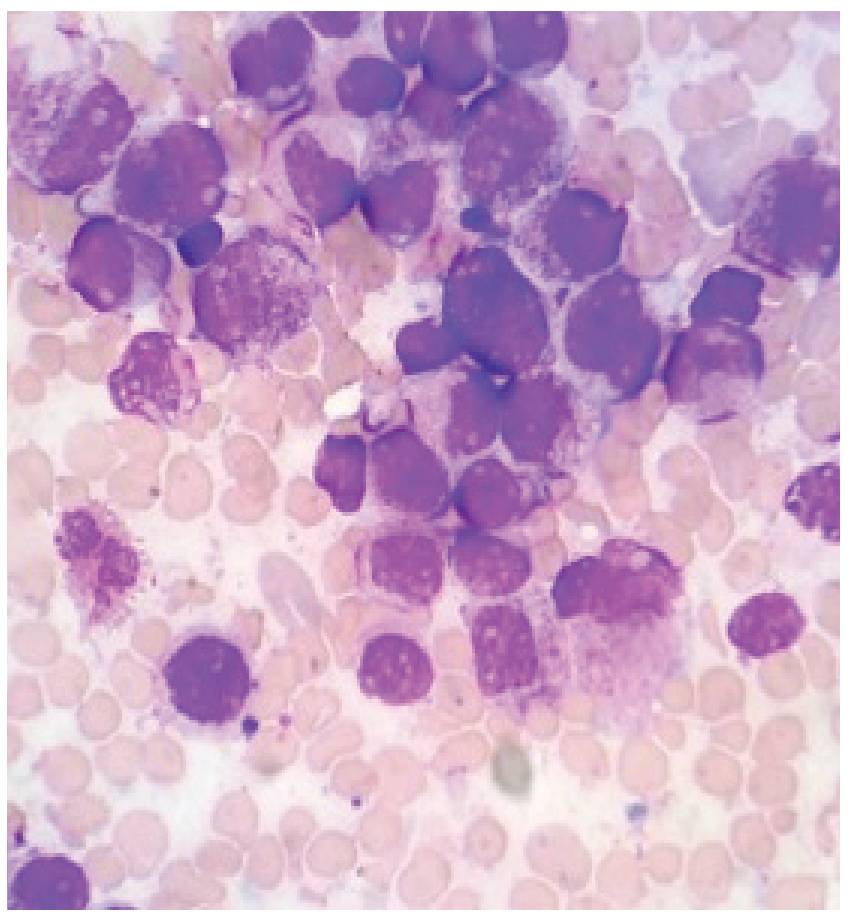

Fig. 1. Bone marrow aspiration
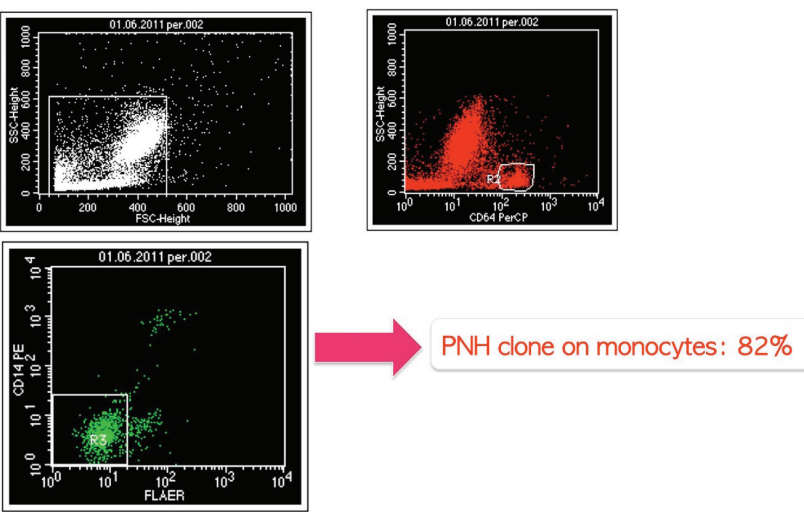

Fig. 2. FLAER revealed a PNH monocyte clone of $82 \%$

\section{Discussion}

$\mathrm{PNH}$ is a rare disorder with a minimum prevalence estimated to 1-1.5 cases per million [4]. Incidence of APL is unknown; it is also a relatively rare hematologic malignancy. The number of newly diagnosed cases per year in the United States is estimated to be 600 to $800[5,6]$. Leukemia can be derived from the clones other than PNH clone in PNH patients [7]. We could not demonstrate that the APL blasts evolved from PNH clone in our patient, since the diagnosis was made after her death. However, catastrophic thromboembolic event that could not be controlled with aggressive anticoagulation in a profoundly thrombocytopenic patient without overt DIC may be suggested as a result of co-existent PNH. In case of atypical thromboembolic events during the course of acute leukemia, probability of underlying PNH should be considered.

Conflict of Interest: The authors declare no conflict of interest.

\section{References}

1. Parker CJ. Paroxysmal nocturnal hemoglobinuria. Curr Opin Hematol 2012;19:141-8. doi: 10.1097/ MOH.0b013e328351c348

2. Harris JW, Koscick R, Lazarus HM, Eshleman JR, Medof ME. Leukemia arising out of paroxysmal nocturnal hemoglobinuria. Leuk Lymphoma 1999;32:401-26.

3. Levi M, Toh CH, Thachil J, Watson HG. Guidelines for the diagnosis and management of disseminated intravascular coagulation. Br J Haematol 2009;145:24-33. doi: 10.1111/j. 13652141.2009.07600.x.

4. Parker C, Omine M, Richards S, Nishimura J, Bessler M, Ware R, Hillmen P, Luzzatto L, Young N, Kinoshita T, Rosse W, Socié G; International PNH Interest Group. Diagnosis and management of paroxysmal nocturnal hemoglobinuria. Blood 
2005;106:3699-709. doi: 10.1182/blood-2005-04-1717

5. Ribeiro R, Rego R. Management of APL in developing countries: epidemiology, challenges and opportunities for international collaboration. Hematology Am Soc Hematol Educ Program 2006:162-8.

6. Douer D. The epidemiology of acute promyelocytic leukemia. Bailliere's Best Pract Clin Hematol 2003;16:35767. doi: http://dx.doi.org/10.1016/S1521-6926(03)00065-3

7. Mortazavi Y, Tooze JA, Gordon-Smith EC, Rutherford TR. N-RAS gene mutation in patients with aplastic anemia and aplastic anemia/ paroxysmal nocturnal hemoglobinuria during evolution to clonal disease. Blood 2000;95:646-50. 